\title{
Africa-Centred Consciousness versus Liberalism in Selected Novels by South African Nadine Gordimer
}

\author{
Hellen Roselyne L . Shigali, PhD \\ Associate Professor \\ Dept. of Literature, Theatre \& Film Studies \\ Moi University \\ Main Campus \\ Eldoret, Kenya
}

\begin{abstract}
Nadine Gordimer, the late South African white writer and 1991 Nobel Laureate for Literature, was involved in the debates on African Literature, starting with the one on definitions in the 1960s and 1970s. She argued that the African writer and literary text are to be defined, not by the writer's skin colour, but on the basis of the individual author's Africa-centred consciousnesss. This parameter appeared contestable in the South African context of the racist apartheid system spanning from 1948 to 1994. At the time, the characteristics of a literary text that exhibits Africa-centred consciousness were not clearly defined. The onus of definition and verification of the same seemed to be left to the critic. In this paper, we assume that representation of certain concepts and ideologies are some of the characteristics that denote Africa-centred consciousness. In Gordimer's case, her representation-cum- contestation of the ideology and practice of liberalism constitutes a significant indicator of her Africa-centred consciousness. In her three novels: Occasion for Loving (1963), The Late Bourgeois World (1966) and Burger's Daughter (1979), she portrays liberalism as a defeatist ideology ,incapable of achieving genuine liberation from the racist apartheid system. In these novels, Gordimer negates the contradictory liberating function of liberalism by creating plot structures in which all individualistic, interracial relationships inevitably fail. At surface level, such denouement seems to affirm the racist policy of apartheid and Gordimer as a non-African advocate of the colour-bar. But I argue for the reverse--that the ending instead reaffirms Gordimers' Africa-centred consciousness which enables her to facilitate conscientisation of her immediate target audience. She succeeds in making many valid cases against the limitations of liberalist reformist effect, as opposed to its purported liberating function. Hence, the title of this paper which pits Gordimer's Africa-centred consciousness that epitomises commitment to genuine liberation from apartheid, against the simplistic reformism of liberalism that is tantamount to a survival strategy of apartheid.
\end{abstract}

Keywords: Apartheid, colour bar, liberalism, liberation, Africa-centred consciousness, African literature, African writer, ideology,

\section{Introduction}

African fiction can be divided into several categories including a racial one distinguishing literary works by black from those by white writers. The latter can be further subdivided into two groups: non-African whites writing about the continent from abroad and indigenous whites writing from within. The position of the former who write from both geographical and often ideological distance is almost predictable and uncontroversial. But it is the standpoint of the indigenous whites which is debatable. At surface level , Gordimer may appear to belong to the latter category who occupy an assumed grey area. Within South Africa, there is yet another subdivision of white writers, separating those who left the country in protest against apartheid system, and those who remained. The stereotypical assumption is that the latter group survived because they wrote either proapartheid works, or those that were simply neutral and uncritical of the system. However, a keen interpretation of Gordimer's works contradicts this assumption in many ways. Her Nobel Prize for Literature 1991 is yet another evaluation of her works as anti-apartheid African literature. 
The Prize was acclaimed by most black Africans including members of the African National Congress, who viewed the honour bestowed on the author as a tribute to all South Africans opposed to the system of apartheid. Underlying the acclamation are two assumptions: Firstly, that Gordimer's writing constitutes African literature in the sense of portraying African experience realistically and empathetically. Secondly, that her political stance against apartheid, which is clearly stated in her non-fiction writing, is positively reflected in her writing.

In an interview with Los Angeles Times, soon after she won the Nobel Prize, Gordimer restated her roles in South Africa thus: "One as a writer and another one, my commitment to the cause of freedom in South Africa and creating a new post-apartheid culture". Her representation of liberalism in the three novels listed above exemplifies these assumptions. African critics have also acclaimed Gordimer's works, among them is the late renowned Professor Abiola Irele. His definition of the African writer seems to be an elaboration of Gordimer's concept of Africa-centred consciousness. In his article, 'The Criticism of Modern African Literature' (1975), he argues that "Our writers are recognisably African only in the sense in which they give an African character to their works and conversely, we who are Africans will only accept them as speaking about us and for us in so far as they take our voices and speak in our accent. The work of criticism of modern African literature must be brought to recognise this fact ( Irele: 1975,p.15)". This argument relates to the controversy surrounding Gordimer's ending of interracial relationships. In exposing the limitations of liberalism, in the three novels, she does in fact speak in the accent of the South African blacks who needed revolution, as opposed to liberalist reform of apartheid system.

\section{Literature Review}

Criticism of Gordimer's works to date is limited, considering the volume of fiction she has produced. Stephen Clingman (1986), is one of her most comprehensive critics. In his thesis 'The Novels of Gordimer, History from the Inside', he examines her depiction of historical experience of apartheid as a resident from the inside. He uses her depiction of historical consciousness as a parameter for situating her novels in African literature. As Clingman rightly argues, "African history is intrinsically bound up with historical circumstances" (1986, p. 10). But he does not qualify her historical consciousness. Failure to do so entails an inadequate parameter because each writer selects historical material and uses it for a given purpose. All fiction in South Africa has historical consciousness ranging from Sarah Getrude Millin, who views blacks as God's Stepchildren, to Nelson Mandela's autobiography , No Easy Walk to Freedom. It is therefore imperative to qualify the worldview of a given author and specific text. Clingman concludes that Gordimer does not write directly for the black community from which she is understandably, legally separated. This view is relevant to this paper in which I attempt to show that Gordimer's Africa-centred consciousness enables her to explore historical consciousness from black South Africans' perspective in order to problematise and consequently negate the function of liberalism in the struggle against apartheid.

In Art and Ideology in the African Novel (1985), Emmanuel Ngara censures Gordimer as a westerner, non-African writer. In his interpretation of The Late Bourgeois World, he concludes that Gordimer merges the socio-political problem of South Africa with that of mankind which she rather romanticizes. She succeeds in portraying her own vision as a westerner, but leaves the reader with no clue as to how the immediate problem in contemporary South Africa might be resolved or what direction the country is taking $(1985, \mathrm{p} .103)$. Ngara's criticism in this instance is not valid. The novel ends, as it logically should, on an ambiguous note that does not project a bright future for the liberation struggle. Gordimer deliberately and justifiably portrays the liberals who are in fact a hindrance to genuine liberation, as a dying lot. This connotes a similar fate for the ideology, values, and attitudes of the class. In a sense, this is indirect optimism. Indeed, she does not proceed to outline a procedure for African take-o ver , because liberalist ideology and practice is incapable of achieving such transformation. This is realistic, because such was the South African political scenario in the 1960s. In the face of extreme repression, the revolutionary liberation movement led by ANC operated either underground or in exile. It seemed to lack a sense of direction at the time. When he calls for solutions under these circumstances, Ngara seems to be lifting the text from its setting in time. He probably bases his interpretation on socialist realism, as distinct from critical realism which defines the novella. In critical realism, the truthful depiction of a situation is in part a solution. Ngara goes further to test Gordimer's characterisation and setting against Friedrich Engels' theory of realism. He acknowledges their typicality, but refutes that of the setting. At this point, Ngara's criticism implies typicality in a reflected sense which borders on topicality, and might even approximate to propaganda. Gordimer's view of literary realism versus topicality may offer her defense in this case. 
She once said that she "picks up where the news bulletins from South Africa have left off". This paper assumes that a solution which suggests a definite way forward, would not be expected in the context of this novella because the author's verdict negates the efficacy of liberalism as strategy against apartheid. According to Gordimer's portrayal, the ideology could only enhance the racist status quo, therefore offering a positive solution would have been an anti-thesis.

In his review of Gordimer's collection of short stories Jump (1991), Dick Roraback observes absence of preachment in her work:" As a conscience of the white South African Gordimer could be expected to pose there and pontificate. Instead in the best African tradition, she favours the role of the "griot" "a storyteller, who encourages her auditors to draw their own conclusions from the behaviour of the characters she conjures up out of an endless imagination (Los Angeles Times October 6 1991)". Roraback's assumption of the griot's impartiality is mispleading. The African institution of the griot is both didactic and ideological. Roraback's idea of impartiality connotes neutrality rather than detachment. The reviewer may have missed the irony in his statement By equating Gordimer to a griot, he inadvertently implies that she has a supportive connection to the apartheid regime. This point is also relevant to this paper in a contrary sense. In her representation of liberalism, Gordimer is not neutral. In as much as she does not offer a solution for the oppressed, she pronounces a clear verdict on inadequacy, inefficacy, and even irrelevance of liberalism in black South Africans' struggle against apartheid. This verdict explains Gordimer's negation of any meaningful inter-racial relationships.

In her article on 'African Mosaic in the Novels of Nadine Gordimer '(1973), Ursula Laredo describes the author's view as pessimistic citing the example of the failed interracial relationship in Occasion for Loving. Laredo does not interpret the text in its historical context and consequently misses Gordimer's deeper analysis of liberalism as individualist, cosmetic and therefore a non-solution to the complex racist apartheid system. On the surface, it is a pity that all the inter-racial relationships in Gordimer's novels fail. But the deeper question is why they must inevitably fail? The justification for the failure is discussed below.

The literature reviewed above justifies the purpose of this paper namely: to correct the misinterpretations and justify Gordimer's valid negation of liberalism as a function of genuine liberation. One of the artistic strategies she explores to achieve this is to destroy inter-racial relationships which paradoxically appears to contradict her very commitment to black South African struggle against the colour bar.

\section{Interrogating liberalism versus Africa-Centred perspective}

The ideology of liberalism outlines individualistic solutions to socio-economic and political problems which by their very nature are communal and nationalistic. The assumption that racism could be eliminated if human beings only related as equals, is negated by the official policy that outlaws racial equality. Liberalists in South Africa did not relate one's individual attitudes to socio-economic status based on colour. In other words, the adv of the proponents of the ideology propose resolution of a complex national crisis at personal level. Such is the assumption of Peter Abrahams' Mine Boy (1946). The central character Xuma is advised to see himself first as a man - meaning as common humanity-- and only thereafter as a black man or white man. Gordimer challenges this worldview. In the selected three novels, she advances the view that liberalism is a non-solution to South African apartheid system which idealises race above common humanity. This perspective is best demonstrated in interracial relationships advanced by both white and black liberalists.

Occasion for Loving (1963) is about Gideon Shibalo, a black painter, who finds himself in the company of white South African liberals, and later in a love affair with Ann Davis-- a visitor from England. The author uses the plot to critique liberalist assumptions through self evaluation by the whites who epitomise its values. Tom and Jessie Stilwell, Boaz and Ann Davis are prompted to cross-examine the merits of the ideology. In the process they are able to problematise their perceptions of both racialism and liberalism. These white liberals ultimately discover that apartheid is a communal-nationalistic problem that is too deeply rooted in the fabric of the entire society, to be resolved at a personal level only. They conclude that, genuine inter-racial interpersonal relationship is virtually impossible under apartheid. It can never have integrity so long as it remains an illicit and in fact criminal connection, under the discriminatory law of the colour bar. This means that individual freedom is intricately intertwined with communal freedoms. At the end of the novel, it is Tom Stilwell who proposes an alternative strategy for the liberation of South Africa from racialist apartheid system. His proposal confirms Gordimer's negation of liberalism as a political strategy for the liberation of South African. Tom Stilwell is portrayed as a liberal academician who advocates multi-racial university education. 
When he first appears in the novel, he is involved in a campaign against a University Bill designed to out-law non-whites from whites' universities. He correctly argues that this is an infringement on academic freedom. This noble-sounding argument is rudely discredited by a black student at a meeting. The student argues that the Bill is not a new law since non-whites have hitherto been excluded from sports and social events. Stilwell's superficial perception of inclusivity and freedom is challenged by the student's logical understanding which supersedes the simplistic liberalist reformist approach to the problem. The contrast between teacher and student in the debate foregrounds Stilwell's naivety, and by inference that of the ideology he epitomises.

The very nature of Stilwell's involvement in the campaign is further challenged by one of his black acquaintance thereby dismissing his non-productive effort. "Fight them over this business if you want to, man, but don't think that anything you do matters. Some of you make laws, and some of you try to change them. And you don't ask us (Gordimer : 1963, p.65).By inference Stilwell's acquaintance does not see any difference between perpetuators of apartheid and liberal whites. In the views of both groups, blacks do not have the freedom to think for themselves. So what exactly is academic freedom? Tom Stilwell's scholarship is also suspect .He is a liberal historian rewriting history from what his wife terms "the black point of view", although he himself refutes it. His wife Jessie, who is one of the critical voices in the novel, accurately discerns the motive of his research as simply another attempt to blackmail the African. "You can assure yourself of glory in the future, in heaven but if that seems too nebulous for you - and the Africans are sick waiting for things - you can assure yourself of glory in the past. It will have exactly the same sort of effect on you, in the present. You'll feel yourself in spite of everything, worthy of either your future or your past (ibid. p. 15)". Scrutinised from his wife's analysis, Stilwell's denial that his interpretation is historical, as distinct from the black point of view, acquires a new connotation. It becomes evident that his research will not change the racist construction of African history. Like his participation in the campaign against the university Bill, his research is inconsequential 1 to black South Africans' struggle to end apartheid.

In addition to exposing his shallow reasoning, Stilwell's academic credentials are further debased by his association with Boaz Davis' research. The latter is a Jewish musicologist studying "primitive music and instruments" on the verge of extinction. The objective of the research sounds noble but the title contradicts its very purpose. Davis's involvement in the study is depicted as an obsession, rather than intellectual exercise. He comes to the research field with an all-knowing attitude that negates the very concept. His work is further trivialised by his wife's attitude to it, which is a combination of existentialism and adventure. That explains why she gets involved in a love affair with Shibalo. Davis abandons his research as abruptly as his wife abandons her extra-marital affair. Juxtaposition of the contrasting preoccupations degrades the supposedly academic research to the level of Ann Davis's thoughtless, adventurous and non-committal illicit involvement with a black lover. The two researchers' work exemplifies the deeply entrenched racist reality that obviously delimits the utopian liberating function of liberalist ideology and practice. In Occasion for Loving, Gordimer achieves what Paul Bailey states in the introduction to the novel, that she does not write "the stuff that is calculated to warm the hearts of liberals everywhere". Bailey also concludes that, Gordimer does not portray any "noble blacks" or any "especially evil whites ". Indeed, why should she romanticize the characters from either race, when both are simply creations of a system which they mistakenly assume they can change, with an inherently limited ideology?

Whereas contradictions and evasions emerge as the distinctive features of liberalism in Occasion for Loving (1963), confusion is dominant in The Late Bourgeois World (1966). From the beginning of the novella, confusion is symbolised by an epigraph which Gordimer borrows from Frantz Kafka: "There are possibilities for me: but under what stone do they lie?" The confusion in liberalist ideology is symbolised by Max the main character of the story while the limitation of the ideology is symbolised by the brevity of his life and death. Indeed, in this novella Gordimer portrays the "late" as in dead-deceased liberalism, which is no longer relevant to South African struggle in the context of the story. The death of Max is a metaphorical verdict. One is reminded of Ngara's invalid conclusion that the Gordimer does not offer any direction in this novel. On the contrary, she does, in an artistic way.

The Story of Max is narrated posthumously in a single day from the point of view of his ex-wife Elizabeth Van Den Sandt. She presents him as a man of good intentions, for Gordimer, so are all the naive liberals, but confused. Max's background is typically bourgeois. His father is a former member of the South African parliament. Max defects from the system to support blacks' liberation struggle. But he is ill-equipped for the demands of the struggle. 
He is unable to reprogram the parasitic dependence on the labour of others which he has lived with all his life. He joins the movement with racist attitudes. His individualistic background makes him crave acknowledgment as a form of reward. Therefore his involvement is not out of genuine commitment to a worthy cause. Max does not have any identifiable specialisation. His probable achievements are summed up by his ex-wife in uncertain terms as follows "Perhaps he might have written something - he had passion and imagination: there were attempts, but he needed day- to - day involvement with others too much to be to be able to withhold himself in the inner concentration that I imagine a writer needs. He might have been a lawyer; but all professions were part of white club whose life membership ticket, his birth right, he had torn up. He might have been a politician, even (it was in the family after all), if political ambitions outside maintenance of white power had been recognized. He might even have been a good revolutionary, if there had been a little more time, before radical movements are banned for him to acquire political discipline. There are possibilities for me, but under what stone do they lie (ibid. P.45)?"

In other words, Max represents a type of white liberal with many handicaps owing to his typical bourgeois background. He has nothing to offer the liberation struggle. Through Elizabeth, the reader is introduced to the blacks with whom Max interacts such as Spears Qwabe and others in several political parties. This character argues that all political parties in South Africa at the time lacked direction. Elizabeth is a liberal in her own right. She associates with blacks and makes some contributions to the liberation movement such as keeping their documents and hosting black activists. But she finds them inconsistent. Luke Fokase and his friends take loans from her but default on repayment. Gordimer's use of Elizabeth's introspective narration through reminiscence achieves a monologue that erases the participation of all the other characters, thereby diminishing their stature. These terminal features and impending end of liberalism portrayed in the two novels above, recur in Burger's Daughter (1979).

Unlike the central liberals of the preceding texts, Rosa Burger inherits a liberal tradition from her parents. Yet in spite of the presumed continuity, liberalism is still portrayed as contradictory, inconsistent and evasive ideology, unsuitable for the South African struggle against apartheid. The novel offers ideal space for much deeper interrogation of the ideology. Rosa Burger's father Lionel Burger is represented as a committed activist who makes great contribution to the liberation movement. Nonetheless, he is still subject to the limitations of white liberalism. Burger's Daughter demonstrates the utmost extent of liberalism, but which still falls far too short as a strategy for dismantling apartheid. Lionel Burger initially defects from an extremist Afrikaner background and joins the Communist Party that is eventually banned. His commitment is assumed to be unquestionable and exemplary until it is re-evaluated by Zwelinzima Vulindlela alias Bassie who was raised in Burger's home. Vulindlela is the one African character who might be considered to have benefitted from white liberalism individually, yet he dismisses the ideology as exploitative. This basically adapted child into the Burger family concludes that Lionel Burger's contribution and subsequent publicity is out of proportion, at the expense of blacks who have sacrificed much more. He cites his biological father as a victim of the erasure of the contribution of black South Africans to the struggle. This is an ideal example of the contradictions embedded in the core principles of liberalism. It implies that whatever white liberals consider to be their contribution to the struggle against apartheid, is paradoxically, equally exploitative. For this black character, the participation of white liberals in the struggle is tantamount to a take-over of the process, without the benefit of ultimate socio-political transformation.

The crucial argument in this novel is summarised thus, "All collaboration with whites has always ended in exploitation of the blacks" (ibid. P. 159). For example, participation of blacks in sports is a bait for the country' $s$ readmission into international sports. Explicitly, liberalism in sports is detrimental to the communal struggle against apartheid. It creates the facade of change in the law of colour bar. Simultaneously, liberalism stratifies the black community, thereby complicating the struggle. In this sense, all collaborators such black police and middle class are portrayed as counter-liberation forces.

White liberalism will sacrifice the long odds on attaining social justice and settle for letting blacks into exploiting class. The 'enlightened' government crowd will sacrifice long odds on maintaining white supremacy and settle for propping up a black middle class whose interests run counter to a black revolution"( ibid. p. 156).

Whether or not the development of a black bourgeois was possible at the time, is not the issue. The major issue revolves around the paradoxical anti-liberation function of liberalism which militates against any lasting benefits from the ideology. 
White female liberals' activities are similarly dismissed as valueless. A meeting at one Flora Donaldson's residence provides a plausible setting for investigation into the role of white women in black women's arm of the liberation struggle. The hostess is a reputed liberal credited with sheltering Nelson Mandela at one time - a feat suggestive of her political enlightenment. Ironically, her brand of liberalism is further narrowed to what her husband William describes as "harmless liberal activities" associated with black women's organisations. Membership in her group is in turn restricted to "the representatives of various organizations, with few outstanding individuals" (ibid, p.200). There is constant reference to the liberalist core principle of individualism throughout, but there is no mention of the need to include the entire oppressed black community. The chosen few individuals are represented by the likes of Daphne Mkhonza who typifies a black exploiter class whose interests are identical with those of the white bourgeoisie.

The other women at the meeting are poor blacks who have resigned themselves to their situation. They gratefully accept the little that the system offers them. The function of the interaction is even further limited by the agenda of the meeting that strictly restricted to social problems (as if they are divorced from apartheid politics). The harmlessness-cum-inconsequential function of the meeting is aptly exposed through the black women's humble requests: "Dressed in their best, one after another, black women in wigs and two-piece dresses pleaded; were complaining, opportuning for cre'ches, orphans, blind, crippled or aged of their 'place'. They asked for the 'old' cots, 'old' school primers, 'old' toys and furniture; 'old' Braille typewriters; 'old' building material. They had come through the front door but the logic was still of the back door. They didn't believe they'd get anything but what was cast-off; they didn't any of them, believe there was anything else to be had from white women, it was all they were good for (ibid. p.203)". Why would any writer, committed or not, want to celebrate such demeaning relationships? At the risk of being misinterpreted as being pro-colour bar Gordimer realistically destroys such relationships. A freelance journalist in attendance protests against the suggestion to "launch a courtesy year to promote understanding between the races "the theme of which is "SMILE AND SAY THANKS". Her tirade could as well be authorial intrusion. "Thank you for what? Maybe the lady has plenty to thank for. But was the object of action for women to make black women 'thankful' for the hovels they lived in, the menial jobs their men did, the inferior education their children got...Thankful for the humiliation dealt out to them by white women living privileged, protected lives, who had the vote and made laws - And so on and so on (ibid. p. 209)". The organisations are strategically restricted to very few individuals, yet their proposal mentions promoting understanding between the races. Liberalist individualism neither aims at, nor is it capable of achieving this. The journalist's genuine concerns are ignored. This exemplifies the evasion of reality by liberalists. Their superficiality is reinforced by hypocritical attempt to cover up the harsh political reality yet it is evident in every situation. There are many more episodes in Burgers Daughter that interrogate the fallacies of liberalism.

\section{Conclusion}

In Occasion for Loving, The Late Bourgeois World, and Burger's Daughter, the African is depicted as a disadvantaged associate of the white liberal. Liberalism advocates multi-racialism which should bring together whites and non-white groups who are willing to interact with one another despite legalised inequality in apartheid system. Gordimer is not opposed to inter-racial socialization per se. But her logical contention is that, for all its noble-sounding core principles, liberalism is only reformist and therefore incapable of dismantling apartheid. She insists that white liberals cannot sincerely believe in the equality of blacks within apartheid system. All that the white liberals can do is to secretly and illegally accommodate a few black individuals on their side of the colour bar. Without destroying the very colour bar which is the core principle of apartheid, meaningful multiracialism is unachievable. It is naive, illogical, unrealistic and even hypocritical for liberals to ignore this fact. Liberalist' view that colour does not matter is negated by all reality in apartheid system. Black South Africans are victimized by the system precisely because of their colour. But their struggle against the system is not a war for neutralization of colour. What blacks demand is recognition for equality as human beings, despite their blackness. The apology for their colour which white liberals attempt to make is in itself discriminatory. Gordimer scrutinises white liberals' faith in the principles, they profess and finds them wanting. She create plausible opportunities for them to prove that faith, but they fail to. In this case, the author is not advancing racism. On the contrary, she aims to prompt both white and black liberals, and her readers, to a deeper understanding of the complexity of apartheid and inadequacy of liberalism as a liberation strategy. Temporary cooption of a few blacks across the colour bar is self-defeating. Interestingly, the purported inclusion is one way. It is the blacks who visit white liberal residences and never the reverse. 
But the reality is that liberalism is incapable of accommodating entire races across the colour bar. This leads to the author's double verdict on the ideology, that it is both inconsequential and simultaneously detrimental to South African liberation struggle. In other words, liberalism and nationalism-cum-transformative liberation are mutually exclusive.

When the white liberal plays the role of apologist for apartheid system such as the academia in Burger's Daughter, he appears harmless, but subsequently gives the system a facelift. Alternatively, he opts for overt survival mechanism such Flora Donaldson in the same novel. The two functions are not mutually exclusive. Both antagonise the liberation struggle by creating divisions among the blacks. In this situation, it would be unrealistic for Gordimer to create dignified blacks. Typical black people who end up as culprits of liberalism are often those already alienated from their community and yet, they can never truly fit in the white group. The blacks' motives for associating with white liberals are intricately linked with psychological attitudes of inferiority created by apartheid system. Given the magnitude of racialism, Gordimer maintains that a fighting option is that only solution. Indeed, there are no effective fighting activities in the novels' realistic contexts. It is noteworthy that on negation of liberalism as a liberation strategy, history has vindicated Gordimer's school of thought, and she lived to witness it for two decades, 1994-2004.

\section{References}

Abrahams, Peter. (1946, 1997 Edition). Mine Boy. Nairobi: East African Educational Publishers. Clingman, Stephen. (1986). The Novels of Nadine Gordimer: History from Inside. London: Allen\& Unwin. Gordimer, Nadine. (1963). Occasion for Loving. London: Virago.

Gordimer, Nadine. (1966). The Late Bourgeois World. London: Virago.

Gordimer, Nadine. (1979). Burger's Daughter. London: Penguin.

Irele, Abiola. (1973) . The African Experience in Literature and Ideology. London: Heinemann.

Laredo, Ursula. (1973). 'Africa Mosaic: The Novels of Nadine Gordimer', in Journal of

Commonwealth Literature Vol. 8 No. 1 pp. 42 - 53.

Ngara, Emmanuel. (1985). Art and Ideology in the African Novel. London: Heinemann.

Roraback, Dick. (1991). 'Gordimer in Details ‘. Los Angeles Times October 6, 1991.

Internet Sources on Liberalism http:// www.associatedcontent.com http://www.rockingphilosophy.com https:// www.learnliberty.com 